\title{
REPRODUCTIVE PERFORMANCE OF THE MITE Brevipalpus phoenicis (GEIJSKES, 1939) ON CITRUS AND COFFEE, USING LIFE TABLE PARAMETERS
}

\author{
TEODORO, A. V. ${ }^{1}$ and REIS, P. R. ${ }^{2}$ \\ ${ }^{1}$ Departamento de Biologia Animal, Setor de Entomologia, Universidade Federal de Viçosa, \\ CEP 36571-000, Viçosa, Minas Gerais, Brazil \\ ${ }^{2}$ EPAMIG-CTSM/EcoCentro, C. P. 176, CEP 37200-000, Lavras, Minas Gerais, Brazil \\ Correspondence to: Paulo Rebelles Reis, EPAMIG-CTSM/EcoCentro, C. P. 176, CEP 37200-000, \\ Lavras, Minas Gerais, Brazil, e-mail: paulo.rebelles@epamig.ufla.br \\ Received August 9, 2004 - Accepted September 17, 2004 - Distributed August 31, 2006
}

(With 1 figure)

\begin{abstract}
The flat-mite Brevipalpus phoenicis (Geijskes, 1939) (Acari: Tenuipalpidae) is considered important in citrus (Citrus spp.) and coffee plants (Coffea spp.) in Brazil, and is known as the leprosis and coffee ring spot mite, as being a vector of the Citrus Leprosis Rhabdovirus - CitLV and Coffee Ring Spot Virus - CoRSV. The objective of this work is to find out about the reproductive success of B. phoenicis on citric fruits and coffee leaves by fertility life table parameters and its biology. The experiments were carried out in laboratory conditions at $25 \pm 2{ }^{\circ} \mathrm{C}, 70 \pm 10 \%$ of relative humidity and $14 \mathrm{~h}$ of photophase. The lengths of embryonic and post-embryonic periods were different due to the host where the mite was reared. B. phoenicis showed better development and higher survival and fecundity in citric fruits than coffee leaves. The intrinsic rate of the population increase $\left(\mathrm{r}_{\mathrm{m}}\right)$ was 0.128 and 0.090 - females/female/day on citric fruits and coffee leaves, respectively. The citric fruits were more appropriate for the development of $B$. phoenicis than coffee leaves.
\end{abstract}

Keywords: citrus leprosis mite, coffee ringspot mite, Coffea arabica, Citrus sinensis, Tenuipalpidae.

\section{RESUMO}

\section{Desempenho Reprodutivo do Ácaro Brevipalpus phoenicis (Geijskes, 1939) em citros e em cafeeiro, utilizando parâmetros de tabela de vida}

O ácaro Brevipalpus phoenicis (Geijskes, 1939) (Acari: Tenuipalpidae) é considerado importante em citros (Citrus spp.) e cafeeiro (Coffea spp.) no Brasil, sendo conhecido como ácaro da leprose e da manchaanular, por ser vetor dos vírus causadores da leprose em citros, Citrus Leprosis Rhabdovirus - CitLV e da mancha-anular em cafeeiro, Coffee Ring Spot Virus - CoRSVO objetivo deste trabalho foi avaliar o sucesso reprodutivo de $B$. phoenicis, em frutos cítricos e em folhas de cafeeiro, por meio de parâmetros calculados a partir da tabela de vida,de fertilidade e da biologia. Os experimentos foram realizados em laboratório a $25 \pm 2{ }^{\circ} \mathrm{C}, 70 \pm 10 \%$ de umidade relativa e $14 \mathrm{~h}$ de fotofase. Os períodos embrionário e pós-embrionário apresentaram diferenças em função do hospedeiro em que o ácaro foi criado. B. phoenicis teve melhor desenvolvimento, maior sobrevivência e maior fertilidade específica em frutos cítricos do que em folhas de cafeeiro. A taxa intrínseca de crescimento populacional (rm) foi de 0,128 e 0,090 fêmeas/fêmea/dia em frutos cítricos e em folhas de cafeeiro, respectivamente. Os frutos cítricos mostraram-se mais adequados ao desenvolvimento de B. phoenicis do que as folhas de cafeeiro.

Palavras-chave: ácaro da leprose, ácaro da mancha-anular, Coffea arabica, Citrus sinensis, Tenuipalpidae. 


\section{INTRODUCTION}

The flat-mite Brevipalpus phoenicis (Geijskes, 1939) (Acari: Tenuipalpidae) was described in Holland under the name of Tenuipalpus phoenicis Geijskes, 1939 (Geijskes, 1939). It is a polyphagous and cosmopolitan species found in tropical and subtropical areas (Haramoto, 1969). It infests various cultures of economical importance, such as coffee (Coffea spp.), citrus (Citrus spp.), Indian tea [Camellia sinensis (L.) O. Kuntze], peach [Prunus persica (L.) Batsch], papaya (Carica papaya L.), coconut (Coconuts nucifera L.), apple (Malus spp.), pear (Pyrus comunis L.), guava [Psidium guajava (L.)], olive (Olea europaea L.), fig (Ficus carica L.), walnut (Juglans spp.) and grapevine (Vitis spp.) as some of the principal hosts (Jeppson et al., 1975). In Brazil, Reis (1974) mentions 37 hosts of the flat-mite found mostly in fruit plantations and Trindade \& Chiavegato (1994) mentioned 33 hosts found mostly in weeds and ornamental plants.

It is considered important in citrus and coffee plantations in Brazil, where it is known as the citrus leprosis mite and coffee ring spot mite for being a vector of the Citrus Leprosis Rhabdovirus - CitLV (Chiavegato et al., 1982; Gravena et al., 1994) and of the Coffee Ring Spot Virus - CoRSV (Chagas, 1973). The mites are found on leaves, branches and fruit of the citrus (Martinelli et al., 1976) and coffee plantations (Reis et al., 2000), usually in low population densities, but can cause damage due to virus transmission. The biological data of B. phoenicis have already been obtained in several hosts, such as papaya by Haramoto (1969); Indian tea by Oomen (1982) and Kennedy et al. (1996); Oroxylum indicum Vent. and Clerodendron siphonanthus R. Br. by Lal (1978) and in citrus, Citrus sinensis (L.) Osbeck, by Chiavegato (1986), demonstrating that the development and reproduction of the mite vary considerably in relation to the species of host it feeds on. In spite of all the study examples mentioned, there is no study that compares the reproductive performance of $B$ phoenicis in different hosts using the fertility life table. In agreement with Kennedy et al. (1996) the economical importance of B. phoenicis is largely due to its high fertility and survival rate as well as reproductive intensity in the first days of oviposition, diapause absence, thelytokous parthenogenesis as main reproduction forms and polyphagia. The construction of the life table enables us to characterize demographic properties, such as the intrinsic rate of population increase, the net reproduction rate, the necessary time for the population to double, as well as the distribution of different ages of a population (Kennedy et al., 1996) enabling us to evaluate the biotic potential of a species under certain conditions.

Therefore, the objective of this work is to evaluate the reproductive performance of B. phoenicis in two of its main host plants in Brazil (citrus and coffee) parameters calculated from the fertility life table and biology.

\section{MATERIAL AND METHODS}

The biological studies of $B$. phoenicis in citric fruits (C. sinensis) and in coffee leaves (Coffea arabica L.) were accomplished simultaneously at the Laboratório de Acarologia do Centro de Pesquisa em Manejo Integrado de Pragas e Doenças de Plantas - EcoCentro, of the Empresa de Pesquisa Agropecuária de Minas Gerais - EPAMIG, in the Campus of the Universidade Federal de Lavras UFLA, at $25 \pm 2{ }^{\circ} \mathrm{C}, 70 \pm 10 \%$ of relative humidity and $14 \mathrm{~h}$ of photophase. The experimental plot was randomly constituted from an orange or coffee leaf. The number of repetitions varied in relation to the availability of the mites in each phase of the development studied can be seen in Table 1 .

Maintenance rearing in citrus and in coffee plants - Maintenance rearing of the mite in citrus was carried out using fruit from the "Valência" (C. sinensis) variety collected at an orchard where pesticides were not applied. The methodology used was similar to that used by Chiavegato (1986), where the citric fruit was made waterproof by using paraffin, independently separated in an area of $3 \mathrm{~cm}$ of diameter and surrounded by glue (Tanglefoot ${ }^{\circledR}$ ) as an arena for rearing the mite.

Concerning the coffee, the rearing stock was carried out on leaves from the Catuaí Vermelho (C. arabica) variety collected from a plantation around 20 years old, which had not received pesticides. They were placed on a $2 \mathrm{~cm}$ thick sponge, constantly humidified with distilled water, which occupied the whole interior of a $15 \mathrm{~cm}$ diameter by $2 \mathrm{~cm}$ deep Petri dish without a cover. The leaves served as a food source and arena for rearing. Each leaf received a fine layer of hydrophilic cotton of 
TABLE 1

Duration, in days, of life cycle phases of Brevipalpus phoenicis rearing in citric fruit and coffee leaves, at $25 \pm 2{ }^{\circ} \mathrm{C}$, $70 \pm 10 \%$ of relative humidity and $14 \mathrm{~h}$ of photophase.

\begin{tabular}{|l|r|c|c|c|}
\hline \multirow{2}{*}{ Phases of the life cycle } & \multicolumn{2}{|c|}{ Citric fruits } & \multicolumn{2}{c|}{ Coffee leaves } \\
\cline { 2 - 5 } & $\mathbf{n}^{\mathbf{1}}$ & Mean $\pm \mathbf{S E}^{\mathbf{2 , 3}}$ & $\mathbf{n}^{\mathbf{1}}$ & Mean $\pm \mathbf{S E}^{\mathbf{2 , 3}}$ \\
\hline Incubation & 762 & $7.43 \pm 0.54$ & 219 & $10.71 \pm 0.83$ \\
\hline Larva & 35 & $1.88 \pm 0.16$ & 25 & $3.12 \pm 0.23$ \\
\hline Protochrysalis & 35 & $1.49 \pm 0.19$ & 25 & $2.00 \pm 0.22$ \\
\hline Protonymph & 35 & $0.97 \pm 0.12$ & 25 & $2.08 \pm 0.19$ \\
\hline Deutochrysalis & 35 & $1.27 \pm 0.16$ & 25 & $2.04 \pm 0.23$ \\
\hline Deutonymph & 35 & $2.12 \pm 0.27$ & 25 & $2.57 \pm 0.26$ \\
\hline Teleiochrysalis & 35 & $2.11 \pm 0.21$ & 25 & $2.66 \pm 0.27$ \\
\hline Egg-adult & 35 & $17.27 \pm 1.11$ & 25 & $25.18 \pm 1.58$ \\
\hline Longevity & 29 & $38.45 \pm 5.08$ & 23 & $27.46 \pm 4.78$ \\
\hline Pre-oviposition & 29 & $1.84 \pm 0.21$ & 25 & $2.54 \pm 0.59$ \\
\hline Oviposition & 29 & $34.90 \pm 5.03$ & 23 & $22.00 \pm 4.42$ \\
\hline Post-oviposition & 29 & $0.86 \pm 0.59$ & 23 & $2.79 \pm 1.86$ \\
\hline
\end{tabular}

${ }^{1}$ Number of observations; ${ }^{2}$ Standard mean error (SE); ${ }^{3}$ The averages of all analyzed parameters differed significantly among the utilized substrates (citrus and coffee) by the F test at $5 \%$ of significance.

approximately $2 \mathrm{~cm}$ wide overlapping the borders and in contact with the humidified sponge, with the purpose of maintaining the turgescence and to avoid the mites escaping (Reis et al., 1997).

Embryonic development - To collect the eggs and determine the incubation period, females of B. phoenicis were maintained in ten citric fruits and ten coffee leaves, as described in the maintenance rearing, for a period of four hours. The eggs were observed daily at $8 \mathrm{~h}$ a.m. and $4 \mathrm{~h} \mathrm{p.m}$. to determine the moment of the larva eclosion and the viability or percentage of eclosion. 762 and 219 eggs on citrus and coffee were observed, respectively.

Post-embryonic development - At the end of the incubation period, newly hatched larva were individualized in citric fruit and coffee leaves, and observed daily at $8 \mathrm{~h}$ a.m. and $4 \mathrm{~h} \mathrm{p} . \mathrm{m}$. The postembryonic development was studied in 35 citrus larvae and in 25 coffee larvae (repetitions), until reaching the adult phase. In each substratum, they were quantified, in days, the duration and survival of the egg phases, larva, protochrysalis, protonymph, deutochrysalis, deutonymph, teleiochrysalis and egg-adult periods of males and females. In the adult phases, the pre-oviposition, oviposition, postoviposition periods and longevity were observed.

Life history parameters - Parameters were obtained by survival data $\left(l_{x}\right)$ in relation to age $(x)$ and specific fertility $\left(m_{x}\right)$ of 29 individualized females in citric fruits and 23 individualized females in coffee leaves (repetitions). Only females were used because $B$. phoenicis reproduces mainly by deuterotokous parthenogenesis, where nonfertilized eggs can produce either females or males. The experiments were evaluated daily at $5 \mathrm{~h}$ p.m. by counting the number of dead mites and oviposition until the death of all females. The sex ratio, that indicates the proportion of females, was calculated by the quotient between the number of females and the number of females added with the number of males.

Fertility life table - The fertility life table was made starting from the survival rate and specific fertility obtained from parameters of the life history and sex ratio (Birch, 1948; Dinh et al., 1988). Using the data from the life table, calculations were made for the net reproduction rate $\left(\mathrm{R}_{\mathrm{o}}\right)$ or the number of times that the population increased in each generation $\left(\mathrm{R}_{\mathrm{o}}=\Sigma m_{x} \cdot l_{x}\right)$ and the intrinsic rate of increase $\left(\mathrm{r}_{\mathrm{m}}\right)$ which expresses the number of females added to the population per female per day by the Lotka equation (Carey, 1993):

$$
\sum_{x=0}^{T} l_{x} m_{x} e^{-r_{m}(x+1)}=1
$$

Where $\mathrm{T}$ is the class age, $l_{x}$ is the proportion of live females (survival) beginning from the birth until the age $x$, and $m_{x}$ is the number of individuals 
produced by a female in the interval of $x$ to $x+1$. Estimations were also made for the finite reason of increase $(\lambda)$, in other words, the number of times that the population grows a day $\left(\lambda=\mathrm{e}^{r_{m}}\right)$, the average duration of a generation $\left(T=\ln R_{o} / r_{m}\right)$ and the necessary time for the population to double (ln 2/ $\mathrm{r}_{\mathrm{m}}$ ), according to Reis \& Alves (1997) and Reis et al. (1998). The times necessary to reach 50\% mortality (TL50) and 100\% mortality (TL100) were obtained by using the fertility life table. TL50 corresponded to the age $x$ where the survival $\left(l_{x}\right)$ presented a value close to 0.50 (Reis et al., 1998).

\section{RESULTS AND DISCUSSION}

Embryonic period - The shortest incubation period observed for $B$. phoenicis in citric fruits was of 6 days with $12.35 \%$ hatching and the longest was of 9 days with $0.13 \%$ hatching, with an average duration of $7.43 \pm 0.54$ days (Table 1 ). Most of the hatchings $(51.26 \%)$ occurred 6.3 days after laying. On the other hand, when the mite was raised on coffee leaves the shortest embryonic period occurred at 8.7 days with $7.01 \%$ hatching and the longest at 13 days with $0.47 \%$ hatching with an average duration of $10.71 \pm 0.83$ days (Table 1 ). Most of the hatchings (52.34\%) occurred at 9.7 days after laying. In this manner, B. phoenicis presented an incubation period significantly shorter in citrus than in coffee. The viability of the eggs calculated by the number of hatched larvae was of 98.82 in citrus and $97.72 \%$ in coffee.

Chiavegato (1986) found an average period of incubation of $7.71 \pm 0.48$ days in citric fruit at $25 \pm 1{ }^{\circ} \mathrm{C}$ for the same mite, a very close result of that also obtained in this work for citrus. Haramoto (1969) and Kennedy et al. (1996) had already observed average periods of incubation of 9.4 days in papaya at $25^{\circ} \mathrm{C}$, and $9.53 \pm 1.71$ days in Indian tea leaves at $26{ }^{\circ} \mathrm{C}$. These results demonstrate that B. phoenicis presents a variation in the duration of the embryonic period due to the host in which the female develops.

Post-embryonic period - The duration of the immature phases was always significantly shorter in mites raised on citric fruit than in those raised on coffee leaves. The egg-adult period was also significantly shorter in citrus $(17.27 \pm 1.11$ days $)$ than in that of coffee $(25.18 \pm 1.58$ days) (Table 1$)$, which can be an indication that the citrus (in comparison with the two hosts) can be more appropriate for the development of the mite. The egg-adult period found by Chiavegato (1986) is close to that found in this work for the citrus. For the same mite, egg-adult periods observed by Haramoto (1969) in papaya fruits at $25^{\circ} \mathrm{C}$ was of 29.3 days. In Indian tea at $19.1-23.4{ }^{\circ} \mathrm{C}$ the eggadult period observed by Oomen (1982) was of 33.5 days. In $O$. indicum and $C$. siphonanthus at $26.6{ }^{\circ} \mathrm{C}$, as mentioned by $\mathrm{Lal}(1978)$, that same period was of 20.7 and 20.2 days, respectively. The pre-oviposition and post-oviposition periods were significantly shorter in citrus than in coffee, while the inverse was observed for the oviposition period. B. phoenicis continued through oviposition for $34.90 \pm 5.03$ days in citric fruits and $22.00 \pm 4.42$ days in coffee leaves. The duration of the post-embryonic phases, as well as the preoviposition, oviposition and post-oviposition periods varied in agreement with the host in which the mite developed (Table 1).

Life history parameters - The values of the survival rate $\left(l_{x}\right)$ and specific fertility $\left(m_{x}\right)$ of B. phoenicis in citric fruits and coffee leaves are presented in Table 2. The survival rate (proportion of live females at age $x$ ) and the specific fertility (average number of descendants produced by female at age $x$ ) of the mites raised on citric fruit were larger than those of coffee leaves. B. phoenicis presented $1.09 \pm 0.18$ and $0.70 \pm 0.22$ eggs/female/ day on average in citrus and in coffee, respectively (Table 2). By only using unfertilized females, the effect of fecundation was not evaluated in the survival and oviposition of $B$. phoenicis. For another species, the phytophagous mite Oligonychus ilicis (McGregor, 1917) (Acari: Tetranychidae), Reis et al. (1997) found a higher survival and oviposition of females not fecundated in comparison with fecundated females. The higher oviposition of B. phoenicis in citrus rather than in coffee results in a larger population in that host which can be an explanation for the greater importance of the leprosis in citrus than of the ring spot in coffee.

The sex ratio was found to be the same as 1 in citrus (100\% females) and 0.98 (98\% females) in coffee. This high sex ratio was expected because B. phoenicis reproduces mainly by thelytokous parthenogenesis, in other words, non-fecundated females produce females identical to the progenitor (Haramoto, 1969; Helle et al., 1980), sexual repro- 
TABLE 2

Survival rate $\left(l_{x}\right)$ in agreement with the age $(x)$ and specific fertility $\left(m_{x}\right)$ of Brevipalpus phoenicis in the respective hosts, at $25 \pm 2{ }^{\circ} \mathrm{C}, 70 \pm 10 \%$ of relative humidity and $14 \mathrm{~h}$ of photophase.

\begin{tabular}{|c|c|c|c|c|}
\hline \multirow{2}{*}{$\begin{array}{c}X \\
\text { (days) }\end{array}$} & \multicolumn{2}{|c|}{ Citric fruit } & \multicolumn{2}{|c|}{ Coffee leaves } \\
\hline & $l_{x}$ & $\boldsymbol{m}_{x}$ & $l_{x}$ & $m_{x}$ \\
\hline 0 & 1 & 0 & 1 & 0 \\
\hline 19 & 1 & 0.62 & 1 & 0 \\
\hline 20 & 1 & 1.59 & 1 & 0 \\
\hline 21 & 1 & 1.72 & 1 & 0 \\
\hline 22 & 1 & 1.62 & 1 & 0 \\
\hline 23 & 1 & 1.93 & 1 & 0 \\
\hline 24 & 1 & 2.00 & 1 & 0.17 \\
\hline 25 & 1 & 1.90 & 1 & 0.35 \\
\hline 26 & 1 & 1.62 & 1 & 0.69 \\
\hline 27 & 1 & 1.41 & 1 & 1.04 \\
\hline 28 & 1 & 1.38 & 1 & 1.13 \\
\hline 29 & 1 & 1.31 & 1 & 1.30 \\
\hline 30 & 1 & 1.38 & 1 & 1.22 \\
\hline 31 & 1 & 1.27 & 1 & 1.35 \\
\hline 32 & 1 & 1.27 & 1 & 1.35 \\
\hline 33 & 1 & 1.31 & 1 & 1.17 \\
\hline 34 & 1 & 1.07 & 1 & 0.91 \\
\hline 35 & 1 & 1.07 & 1 & 1.04 \\
\hline 36 & 1 & 0.90 & 0.96 & 0.95 \\
\hline 37 & 1 & 0.96 & 0.87 & 1.05 \\
\hline 38 & 1 & 1.10 & 0.83 & 1.00 \\
\hline 39 & 0.96 & 1.03 & 0.83 & 0.89 \\
\hline 40 & 0.96 & 1.14 & 0.78 & 0.83 \\
\hline 41 & 0.93 & 1.00 & 0.78 & 0.72 \\
\hline 42 & 0.90 & 1.11 & 0.78 & 0.55 \\
\hline 43 & 0.86 & 0.96 & 0.74 & 0.53 \\
\hline 44 & 0.83 & 1.08 & 0.69 & 0.50 \\
\hline 45 & 0.83 & 0.96 & 0.69 & 0.62 \\
\hline 46 & 0.76 & 1.14 & 0.69 & 0.87 \\
\hline 47 & 0.76 & 1.18 & 0.61 & 0.57 \\
\hline 48 & 0.70 & 1.00 & 0.56 & 0.85 \\
\hline 49 & 0.65 & 0.95 & 0.52 & 0.75 \\
\hline 50 & 0.65 & 0.84 & 0.48 & 0.64 \\
\hline 51 & 0.65 & 0.84 & 0.43 & 0.70 \\
\hline 52 & 0.58 & 0.76 & 0.43 & 0.50 \\
\hline 53 & 0.55 & 0.94 & 0.43 & 0.30 \\
\hline 54 & 0.48 & 0.78 & 0.39 & 0.33 \\
\hline 55 & 0.45 & 0.85 & 0.30 & 0.14 \\
\hline 56 & 0.41 & 0.77 & 0.26 & 0.50 \\
\hline 57 & 0.38 & 0.73 & 0.22 & 0.60 \\
\hline 58 & 0.34 & 1.10 & 0.13 & 0.67 \\
\hline 59 & 0.31 & 0.55 & 0.13 & 0.00 \\
\hline 60 & 0.31 & 1.44 & 0.13 & 0.33 \\
\hline 61 & 0.31 & 0.67 & 0.13 & 0.67 \\
\hline 62 & 0.31 & 0.67 & 0.09 & 0.00 \\
\hline 63 & 0.27 & 0.75 & 0.04 & 2.00 \\
\hline 64 & 0.27 & 0.62 & 0.04 & 0.00 \\
\hline 65 & 0.27 & 0.75 & 0.04 & 1.00 \\
\hline 66 & 0.21 & 0.67 & 0.04 & 1.00 \\
\hline
\end{tabular}


TABLE 2

Continued...

\begin{tabular}{|c|c|c|c|c|}
\hline \multirow{2}{*}{$\begin{array}{c}\boldsymbol{X} \\
\text { days })\end{array}$} & \multicolumn{2}{|c|}{ Citric fruit } & \multicolumn{2}{c|}{ Coffee leaves } \\
\cline { 2 - 5 } & $\boldsymbol{l}_{\boldsymbol{x}}$ & $\boldsymbol{m}_{\boldsymbol{x}}$ & $\boldsymbol{l}_{\boldsymbol{x}}$ & $\boldsymbol{m}_{\boldsymbol{x}}$ \\
\hline 67 & 0.14 & 0.75 & 0.04 & 0.00 \\
\hline 68 & 0.03 & 2.00 & 0.04 & 0.00 \\
\hline 69 & 0.03 & 1.00 & 0.04 & 0.00 \\
\hline 70 & 0.03 & 1.00 & 0.04 & 0.00 \\
\hline 71 & 0.03 & 1.00 & 0.04 & 0.00 \\
\hline 72 & 0.03 & 1.00 & $\mathbf{0 . 0 0}$ & 0.00 \\
\hline $\mathbf{7 3}$ & 0.03 & 1.00 & - & - \\
\hline 74 & 0.03 & 1.00 & - & - \\
\hline 75 & 0.03 & 1.00 & - & - \\
\hline 76 & 0.03 & 1.00 & - & - \\
\hline 77 & 0.03 & 0.00 & - & - \\
\hline 78 & $\mathbf{0 . 0 0}$ & 0.00 & & \\
\hline
\end{tabular}

duction with the participation of males also exists, which is rare in the population.

Fertility life table - The intrinsic rate of the population increase $\left(\mathrm{r}_{\mathrm{m}}\right)$ was estimated at $0.128 \mathrm{fe}$ males/female/day in citric fruit and 0.090 females/ female/day in coffee leaves (Fig. 1), demonstrating the influence of the host on the increase rate. The contribution to establish the value of the intrinsic increase rate is higher in the first days due to higher oviposition (Birch, 1948). Therefore, the population increase of $B$. phoenicis is determined by the age in which oviposition begins and by the intensity of this during the first days of oviposition (Kennedy et al., 1996). With the results presented in Table 2, it can be concluded that B. phoenicis began oviposition earlier (shorter pre-oviposition period) and presented a higher number of eggs per female in citric fruit than in coffee leaves, which explains the difference in the $r_{m}$ of the two hosts. The liquid rate of reproduction $\left(\mathrm{R}_{\mathrm{o}}\right.$ ), which indicates the average number of females born during the life span of each female, was 58 in citric fruits and 22.3 in coffee.

The average duration period of a generation (T) was shorter in citric fruits (31.7 days) than in coffee leaves (34.4 days), which means that the population of $B$. phoenicis is estimated to increase 58 times (value of $R_{0}$ ) in about 32 days in citrus and 22 times (value of $R_{\mathrm{o}}$ ) in about 34 days in coffee. A period of 5.4 days in citrus and 7.7 days in coffee was estimated to cause the population of $B$. phoenicis to double. The finite reason of increase $(\lambda)$ was of 1.14 in citrus and 1.10 in coffee, indicating the population increase of $B$. phoenicis per day in the respective hosts.

For the same mite raised on Indian tea at $26{ }^{\circ} \mathrm{C}$, Kennedy et al. (1996) found an $\mathrm{r}_{\mathrm{m}}$ of 0.127 , a finite reason of increase $(\lambda)$ of 1.14 and a liquid rate of reproduction $\left(\mathrm{R}_{\mathrm{o}}\right)$ of 33.2. They also observed a period of 27.6 days for generation and 5.5 days for the population to double. The $r_{m}$ value, the finite reason of increase $(\lambda)$ and the period for the population to double were similar to that found in citric fruit in this work, however the other parameters were different.

The necessary periods for 50 and $100 \%$ of the mite population to die, TL50 and TL 100, were larger for the mites raised on citric fruits. The population presented a TL50 of about 54 and 50 days, and a TL100 of 78 and 73 days for citrus and coffee, respectively (Table 2).

The obtained results enable us to conclude that between the two studied hosts, the most appropriate for the development of B. phoenicis are citric fruit, since the mite presents a reduced embryonic and post-embryonic period in relation to the coffee leaves. Citric fruit also presents the highest values of specific fertility, survival and of the intrinsic increase rate $\left(\mathrm{r}_{\mathrm{m}}\right)$, which indicates it as being a better suitable host for the mite when compared with the coffee leaves.

Acknowledgments - To the Consórcio Brasileiro de Pesquisa e Desenvolvimento do Café - CBP\&D/Café and to the Conselho Nacional de Desenvolvimento Científico e Tecnológico - CNPq for funding the grants and scholarship necessary to carry out this project. 


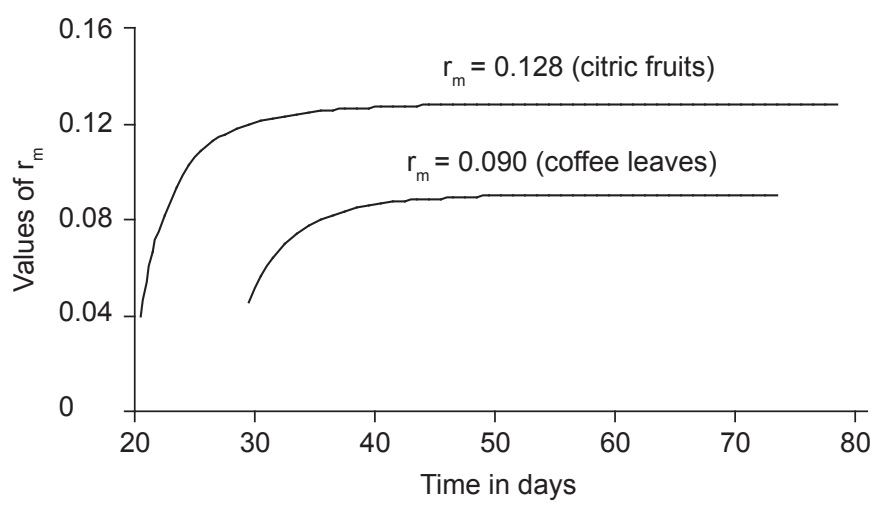

Fig. 1 - Evolution of the intrinsic rate of population increase $\left(\mathrm{r}_{\mathrm{m}}\right)$ of Brevipalpus phoenicis in citric fruit and coffee leaves, at $25 \pm 2{ }^{\circ} \mathrm{C}, 70 \pm 10 \%$ of UR and $14 \mathrm{~h}$ of photophase.

\section{REFERENCES}

BIRCH, L. C., 1948, The intrinsic rate of natural increase of an insect population. J. Anim. Ecol., 17: 15-26.

CAREY, J. R., 1993, Applied demography for biologists with special emphasis on insects. Oxford University Press, New York.

CHAGAS, C. M., 1973, Associação do ácaro Brevipalpus phoenicis (Geijskes) à mancha-anular do cafeeiro. Biológico, 39: 229-232.

CHIAVEGATO, L. G., 1986, Biologia do ácaro Brevipalpus phoenicis em citros. Pesq. Agropec. Bras., 21: 813-816.

CHIAVEGATO, L. G.; MISHAN, M. M. \& SILVA, M. A., 1982, Prejuízos e transmissibilidade de sintomas de leprose pelo ácaro Brevipalpus phoenicis (Geijskes, 1939) Sayed, 1946 (Acari: Tenuipalpidae) em citros. Científica, 10: 265-271.

DINH, N. van; JANSSEN, A. \& SABELIS, M. W., 1988, Reproductive success of Amblyseius idaeus and A. anonymus on a diet of two-spotted spider mites. Exp. Appl. Acarol., 4: 41-51.

GEIJSKES, D. C., 1939, Contributions to the knowledge of European spinning mites with particular reference to the Netherlands species. Arten. Mededelingen van de Landbouwhogescholl Wageningen, 42: 1-68.

GRAVENA, S., BENETOLI, I., MOREIRA, P. H. R. \& YAMAMOTO, P. T., 1994, Euseius citrifolius Denmark \& Muma predation on citrus leprosis mite Brevipalpus phoenicis (Geijskes) (Acari: Phytoseiidae: Tenuipalpidae). An. Soc. Entomol. Brasil, 23: 209-218.

HARAMOTO, F. H., 1969, Biology and control of Brevipalpus phoenicis (Geijskes) (Acarina: Tenuipalpidae). Hawaii Agricultural Experimental Station, Honolulu, 63p. (Technical Bulletin, 68).

HELLE, W., BOLLAND, H. R. \& HEITMANS, W. R. B., 1980, Chromosomes and types of parthenogenesis in the false spider mites (Acari: Tenuipalpidae). Genetica, 54: 45-50.

JEPPSON, L. R., KEIFER, H. H. \& BAKER, E. W., 1975, Mites injurious to economic plants. University of California Press, Berkeley, 614p.
KENNEDY, J. S., IMPE, G. VAN, HANCE, T. \& LEBRUN, P., 1996, Demecology of the false spider mite, Brevipalpus phoenicis (Geijskes) (Acari, Tenuipalpidae). J. Appl. Entomol., 120: 493-499.

LAL, L., 1978, Biology of Brevipalpus phoenicis (Geijskes) (Tenuipalpidae: Acarina). Acarologia, 20: 97-101.

MARTINELLI, N. M., OLIVEIRA, C. A. L. \& PERECIN, D., 1976, Conhecimentos básicos para estudos que envolvam levantamentos da população do ácaro Brevipalpus phoenicis (Geijskes, 1939) na cultura dos citros. Científica, 4: 242253.

OOMEN, P. A., 1982, Studies on population dynamics of the scarlet mite, Brevipalpus phoenicis, a pest of tea on Indonesia.Arten.Mededelingenvande Landbouwhogescholl Wageningen, p. 1-88.

REIS, P. R, 1974, Ácaros de algumas fruteiras de clima tropical e subtropical e seus hospedeiros. ESAL, Lavras, 32p. (Boletim Técnico, Série Pesquisa, 3).

REIS, P. R. \& ALVES, E. B., 1997, Biologia do ácaro predador Euseius alatus DeLeon (Acari: Phytoseiidae). An. Soc. Entomol. Brasil, 26: 359-363.

REIS, P. R., ALVES, E. B. \& SOUSA, E. O., 1997, Biologia do ácaro-vermelho do cafeeiro Oligonychus ilicis (McGregor, 1917). Ciênc. Agrotec., 21: 260-266.

REIS, P. R., CHIAVEGATO, L. G. \& ALVES, E. B., 1998, Biologia de Iphiseiodes zuluagai Denmark \& Muma (Acari: Phytoseiidae). An. Soc. Entomol. Brasil, 27: 185-191.

REIS, P. R., SOUZA, J. C., SOUSA, E. O. \& TEODORO, A. V., 2000, Distribuição espacial do ácaro Brevipalpus phoenicis (Geijskes) (Acari: Tenuipalpidae) em cafeeiro (Coffea arabica L.). An. Soc. Entomol. Brasil, 29: 177-183.

TRINDADE, M. L. B. \& CHIAVEGATO, L. G., 1994, Caracterização biológica dos ácaros Brevipalpus obovatus D., B. californicus B. e B. phoenicis G. (Acari: Tenuipalpidae). An. Soc. Entomol. Brasil, 23: 189-195. 
